\title{
SOME IMPLICATIONS OF THE CHANGES IN THE WORLD POPULATION DISTRIBUTION: HOW GLOBALIZED WILL THE WORLD REMAIN?*
}

\author{
Yu.V. Zinkina ${ }^{1,2}$, S.G. Shulgin ${ }^{1}$, I.A. Aleshkovski ${ }^{2}$, \\ A.I. Andreev ${ }^{2}$ \\ ${ }^{1}$ Russian Presidential Academy of National Economy and Public Administration \\ Prosp. Vernadskogo, 84, Moscow, Russia, 119571 \\ ${ }^{2}$ Lomonosov Moscow State University \\ Leninskie Gory, 1-51, Moscow, 119991, Russia \\ (e-mail: juliazin@list.ru; sergey@shulgin.ru; \\ andreev@fgp.msu.ru; aleshkovski@fgp.msu.ru)
}

\begin{abstract}
For the first-world citizens, globalization seems to be an all-pervasive phenomenon; however, the global connectivity rates differ dramatically for various countries. What will the situation be in, let say, fifty years? The article aims to show how the future demographic changes can influence absolute numbers and relative proportions of societies with different levels of global connectivity. To estimate the national rates of global connectivity the authors rely on the countries' participation in global networks, such as trade in goods, trade in services, foreign direct investment (FDI), and international migration. As the scenario of the demographic future, the authors use medium population projections of 2017 calculated by the United Nations Population Division. The authors applied a two-stage method: first, they constructed network models and analyzed the structure of networks to reveal the positions of countries in order to estimate their rates of global connectivity and identify six groups of countries according to their global connectivity rates. Second, the authors combined the results of network analysis with demographic projections to find out how many people are expected to live in the countries with different connectivity rates in the nearest decades (let say, up to 2050) and in the more distant future (2100). The results show that nearly a half of the world population (3.46 billion) lives in highly-connected countries but the situation will dramatically change in the coming decades. The proportion of population in the highly- and highlymedium-connected countries will decline by 2050 and further by 2100 , while the proportion of residents of medium- and low-connected (and to some extent of lowest-low-connected) countries will significantly grow.
\end{abstract}

Key words: globalization; global connectivity; measurements of globalization; demographic forecasts; world population; population forecasts

The article considers the relationship between globalization and the global demographic landscape to show how the demographic changes can affect globalization (and vice versa) in the nearest and more distant future (until 2100). However, our interpretation of globalization depends on its definition, and we believe that a comprehensive definition providing a multi-dimensional systemic vision of globalization was suggested by the prominent scholar George Modelski who combined two approaches:

* C Yu.V. Zinkina, S.G. Shulgin, I.A. Aleshkovski, A.I. Andreev, 2017.

This research was supported by the Russian Science Foundation. Project No. 17-78-20096. 
(a) 'connectivist' approach defining globalization as the increase of transborder interactions, relations, and flows, and (b) institutional approach defining globalization as the emergence and evolution of global institutions (the term 'institutions' is very wide and includes global free trade, multinational enterprises, global governance, global social movements, ideologies, etc.) [19]. Thus, we select a number of global institutions with network structure determined by transborder interactions and flows, apply network analysis methods to identify the structural position of every country within the networks (define the maximal degree of k-core to which the country belongs and the maximal k-core degree in the whole network (see: [21]), divide the first by the second, and get a figure defining the country's structural position within the global network and reflecting its degree of involvement (i.e. this figure is the country's global connectivity rate). We also describe the global demographic landscape through the prism of globalization the current distribution of the world population among the countries with the highest, medium, low and lowest-low rates of global connectivity. There are forecasts that the future global demographic changes are to be profound and can lead to global turbulence [see: $1 ; 8 ; 10 ; 11 ; 14 ; 16 ; 20 ; 23 ; 27 ; 29$ ].

The article aims as estimating future demographic changes that can influence absolute numbers and relative proportions of population in societies with various levels of global connectivity. We use the medium demographic scenario calculated by the United Nations Population Division [24]. Certainly, demographic changes are not the only factor affecting the distribution of people between countries with varying degrees of global connectivity. Numerous other factors can be named, such as migration policies, economic growth or stagnation, social-political destabilization, natural disasters etc. However, we focus on possible effects of demographic factors as the most reliable forecasts in the long-term (decades) perspective.

In the mid-1990s Manuel Castells presented his research on social structures and suggested that in the information era the most important social functions and processes are increasingly organized in the form of networks: elements of certain networks and relations between networks become one of the most important sources of power in the contemporary 'network society' [3-5]. Castells believes that inclusion in the network or exclusion from it defines the configuration of the most important ongoing social processes, that is why it is important to study the network structure of social processes to understand them. Globalization is one of such processes and a new historical reality. Castells defines globalization as a dominant process of the global scale and a factor affecting numerous dimensions of the society's existence and evolution [4]. Thus, a thorough investigation of the network structure of globalization allows to understand the nature of many other major processes in the spheres of information, culture, governance, etc.

Castell stressed that the network society is built around global network structures of capital, governance, and information, so it is reasonable to start the study of the network structure of globalization with one of them. We chose the economic aspect (capital) for Castells claimed that although globalization is a multidimensional process it can be better understood from the economic perspective $[4 ; 13]$. The choice of networks was 
determined by the new economic geography which finds strong interrelations between three global networks - trade, FDI, and migration [see: 6].

To measure national rates of global connectivity we consider the countries' participation in several global networks such as trade in goods, trade in services, FDI and international migration. The data on country-to-country trade in goods were taken from the UN COMTRADE database according to the Harmonized Commodity Description and Coding Systems classification [25]. We mainly use the data on the total value of import from country A to B and from B to A (in the current dollar prices) or (if the data is missing) of export from B to A (the so-called 'mirroring' accepts export statistics when there is no import statistics; this approach can increase errors as export statistics can differ from import statistics, but such data is still better for network models than no data at all). We use a symmetric approach that allows to apply the model of undirected graph, which simplifies the reality of the global world (conceals all asymmetries between countries, for instance, when trade flow from A to B significantly exceeds the one from B to A). However, even the extremely asymmetrical relations imply the economic connection between $\mathrm{A}$ and $\mathrm{B}$ even if in the form of economic dependency of B on A (or vice versa), and that is the most important point for the analysis of global connectivity rates. Certainly, another approach (directed graphs) is also possible, and we use it elsewhere for similar goals [21].

The data on bilateral trade in services are taken from The Trade in Services database that accumulates data of the OECD, Eurostat, United Nations, and IMF [28]. The data on the accumulated stock of bilateral FDI are obtained from the United Nations COMTRADE database [25]. The data on the accumulated stock of migrants are obtained from the United Nations that publishes data on the migrant stocks by the country of origin for 197 countries every five years from 1990 [26]. We study the structure of these networks during three periods - 2000-2004, 2005-2009, and 2010 - 2017, and rely on the medium demographic scenario calculated by the United Nations Population Division [26].

There are many network metrics that could be used for various research tasks especially in the graph analysis. The key elements of network analysis are actors and relations between them, i.e. nodes and edges of a graph. In the study of global networks one can use such network metrics as a node activity (the number of relations a country has), node strength (the number and weight of relations), centrality (closeness centrality, betweenness centrality, eigenvector centrality, etc.) which characterize the structural position of a country within the network, clusterization coefficient and assortativity coefficient (the structure of relations in the whole network) and so on [see: 2]. For our study we use a two-stage method: first, we construct network models and analyze the structure of networks to identify the positions of countries and the rates of global connectivity; second, we combine the results of the network analysis with demographic data to find out the size of population in countries with different connectivity rates in the nearest decades (until 2050) and more distant future (until 2100).

First stage: network models. For each of four networks we make three matrices $\mathrm{N}^{*} \mathrm{~N}$ (one matrix per each of the three periods), in which $\mathrm{N}$ is the total number of 
countries, and column $i$ presents the relations of the country $i$ with other countries in the given network. A symmetrical matrix of relations is an undirected graph, so we use the network analysis of graphs. Our task is to select not a completely interconnected group, but rather a group of the largest possible size with the largest possible level of interconnectedness. We apply the concept of a k-core - a subset of vertices each of which has not less than $k$ relations with other vertices in this subset. In addition the $k$-core has another noteworthy feature - it allows not only to find vertices (countries) with the highest number of connections, but also identifies countries with the greatest number of connections to other highly-connected countries (sort of a "high connectivity club") [see: 22].

For each country, we find the maximal degree of the k-core to which it belongs $\left(K_{i}\right)$, the maximal k-core in the network $\left(K_{\max }\right)$, and divide $K_{i}$ by $K_{\max }$. The value of $K_{i} / K_{\max }$ for the country $i$ equals to 1 if this country belongs to the k-core of maximal density. Otherwise, for example, $K_{i} / K_{\max }=0.5$ if the country $i$ belongs to the k-core twice smaller than the maximal k-core in the graph. To set another example, $K_{i} / K_{\max }=0$ if the country $i$ is represented by a fully isolated vertex and has no relations with any other country in the network. Thus, for each country we find a value that reflects its position in all four networks (goods, services, FDI, migration). These four rates are then summarized without any extra weights for in every network we find values representing the same structural characteristics of the country that reflect the position of the corresponding vertex within the network. The maximal value of global connectivity for the country is 4 (in all four networks it rates at 1 - this is the highest value possible).

Second stage: demographic data. We rely on the medium demographic scenario of the United Nations Population Division that estimates the size of the population in different countries of the world until 2100. We sum up the forecasts for groups of countries with different global connectivity rates (Table 1).

Table 1

Global connectivity rates (sorted in the descending order for 2010-2017) [22]

\begin{tabular}{|l|c|c|c|}
\hline \multicolumn{1}{|c|}{ Country } & $2000-2004$ & $2005-2009$ & $2010-2017$ \\
\hline United Kingdom & 4 & 4 & 4 \\
\hline United States & 4 & 4 & 4 \\
\hline Germany & 3.999 & 4 & 4 \\
\hline Italy & 3.996 & 4 & 4 \\
\hline France & 3.999 & 4 & 3.995 \\
\hline Spain & 3.994 & 3.994 & 3.982 \\
\hline Netherlands & 3.992 & 3.987 & 3.98 \\
\hline Switzerland & 3.991 & 3.986 & 3.973 \\
\hline Belgium & 3.978 & 3.972 & 3.959 \\
\hline China & 3.917 & 3.952 & 3.944 \\
\hline Japan & 3.952 & 3.947 & 3.919 \\
\hline Canada & 3.951 & 3.96 & 3.907 \\
\hline Russian Federation & 3.628 & 3.913 & 3.895 \\
\hline Ireland & 3.867 & 3.908 & 3.89 \\
\hline Sweden & 3.928 & 3.915 & 3.872 \\
\hline Australia & 3.89 & 3.926 & 3.852 \\
\hline Poland & 3.8 & 3.865 & \\
\hline Korea, Republic of & 3.821 & 3.861 & \\
\hline
\end{tabular}


Zinkina Yu.V. et al. RUDN Journal of Sociology, 2018, 18 (2), 271-283

Continuation of the table 1

\begin{tabular}{|c|c|c|c|}
\hline Country & $2000-2004$ & $2005-2009$ & $2010-2017$ \\
\hline Austria & 3.847 & 3.887 & 3.848 \\
\hline Denmark & 3.879 & 3.86 & 3.823 \\
\hline India & 3.382 & 3.711 & 3.796 \\
\hline Brazil & 3.698 & 3.899 & 3.79 \\
\hline Singapore & 3.727 & 3.747 & 3.78 \\
\hline Norway & 3.821 & 3.819 & 3.757 \\
\hline Hong Kong & 3.754 & 3.752 & 3.751 \\
\hline Turkey & 3.687 & 3.8 & 3.742 \\
\hline Hungary & 3.674 & 3.728 & 3.692 \\
\hline Finland & 3.742 & 3.725 & 3.687 \\
\hline Portugal & 3.794 & 3.731 & 3.663 \\
\hline Czech Republic & 3.546 & 3.648 & 3.646 \\
\hline Luxembourg & 3.547 & 3.581 & 3.588 \\
\hline Greece & 3.621 & 3.637 & 3.56 \\
\hline South Africa & 3.529 & 3.647 & 3.542 \\
\hline Thailand & 3,488 & 3,686 & 3,493 \\
\hline Malaysia & 3,343 & 3,662 & 3,471 \\
\hline Romania & 2,995 & 3,522 & 3,456 \\
\hline Chile & 2,748 & 3,447 & 3,43 \\
\hline Israel & 3,454 & 3,609 & 3,402 \\
\hline Mexico & 3,104 & 3,547 & 3,398 \\
\hline Bulgaria & 3.103 & 3.341 & 3.281 \\
\hline New Zealand & 3.272 & 3.31 & 3.232 \\
\hline Slovakia & 3.096 & 3.252 & 3.229 \\
\hline Indonesia & 3.128 & 3.392 & 3.222 \\
\hline Cyprus & 3.096 & 3.23 & 3.185 \\
\hline Ukraine & 3.061 & 3.167 & 3.129 \\
\hline Philippines & 3.062 & 3.347 & 3.073 \\
\hline Argentina & 3.013 & 3.259 & 3.066 \\
\hline Croatia & 3.071 & 3.074 & 3.026 \\
\hline Pakistan & 2.600 & 3,055 & 2.925 \\
\hline Egypt & 2.91 & 2.799 & 2.922 \\
\hline Lithuania & 2.835 & 2.962 & 2.888 \\
\hline Slovenia & 2.888 & 2.883 & 2.834 \\
\hline Latvia & 2.756 & 2.908 & 2.801 \\
\hline Estonia & 2,734 & 2,833 & 2,793 \\
\hline Morocco & 2,838 & 2,862 & 2,747 \\
\hline United Arab Emirates & 2,88 & 3,169 & 2,715 \\
\hline Malta & 2,349 & 2,657 & 2,703 \\
\hline Venezuela & 2,694 & 2,659 & 2,687 \\
\hline Nigeria & 2,307 & 2,389 & 2,634 \\
\hline Iran & 2.645 & 2.589 & 2.568 \\
\hline Saudi Arabia & 2.834 & 3.405 & 2.557 \\
\hline Kazakhstan & 2.669 & 2.779 & 2.55 \\
\hline Colombia & 2.309 & 2.451 & 2.547 \\
\hline Belarus & 2.342 & 2.529 & 2.433 \\
\hline Iceland & 2.306 & 2.587 & 2.409 \\
\hline Viet Nam & 2.654 & 3.015 & 2.305 \\
\hline Peru & 2.29 & 2.539 & 2.297 \\
\hline Uruguay & 2.061 & 2.152 & 2.227 \\
\hline Kuwait & 2.308 & 2.517 & 2.218 \\
\hline Panama & 2.437 & 2.576 & 2.198 \\
\hline Serbia & 1.135 & 2.17 & 2.19 \\
\hline Bangladesh & 2.225 & 2.357 & 2.158 \\
\hline Qatar & 2.008 & 2.397 & 2.128 \\
\hline Mauritius & 1.691 & 2.051 & 2.114 \\
\hline
\end{tabular}


Зинькина Ю.В. и др. Вестник РУДН. Серия: СОЦИОЛОГИЯ. 2018. Т. 18. № 2. С. 271-283

Continuation of the table 1

\begin{tabular}{|c|c|c|c|}
\hline Country & $2000-2004$ & $2005-2009$ & $2010-2017$ \\
\hline Azerbaijan & 2.073 & 2.38 & 2.079 \\
\hline Algeria & 2.299 & 2.373 & 2.051 \\
\hline Lebanon & 2.261 & 2.267 & 2.015 \\
\hline Jordan & 2.254 & 2.356 & 2.001 \\
\hline Libya & 2.088 & 2.368 & 1.984 \\
\hline Sri Lanka & 2.128 & 2.083 & 1.95 \\
\hline Bahrain & 1.952 & 2.143 & 1.929 \\
\hline Ecuador & 1.991 & 2.078 & 1.906 \\
\hline Costa Rica & 1.873 & 1.968 & 1.861 \\
\hline Georgia & 1.761 & 2.006 & 1.86 \\
\hline Syrian Arab Republic & 2.15 & 2.145 & 1.837 \\
\hline Bosnia and Herzegovina & 1.959 & 2.074 & 1.814 \\
\hline Tunisia & 2.158 & 2.151 & 1.805 \\
\hline Oman & 1.762 & 1.991 & 1.795 \\
\hline Macedonia & 1.775 & 1.791 & 1.757 \\
\hline Albania & 1.691 & 1.712 & 1.754 \\
\hline Ghana & 1.79 & 1.845 & 1.737 \\
\hline Moldova & 1.81 & 1.913 & 1.693 \\
\hline Bermuda & 1.561 & 1.722 & 1.69 \\
\hline Cayman Islands & 1.831 & 1.851 & 1.68 \\
\hline Ethiopia & 1.71 & 1.778 & 1.677 \\
\hline Kenya & 1,865 & 1,895 & 1,669 \\
\hline Yemen & 1,745 & 1,818 & 1,665 \\
\hline Dominican Republic & 1,876 & 1,904 & 1,661 \\
\hline Iraq & 1,761 & 1,764 & 1,655 \\
\hline Armenia & 1,625 & 1,816 & 1,655 \\
\hline Bolivia & 1,615 & 1,649 & 1,63 \\
\hline Kyrgyzstan & 1.647 & 1.7 & 1.627 \\
\hline Guatemala & 1.675 & 1.717 & 1.609 \\
\hline Bahamas & 1.791 & 1.889 & 1.589 \\
\hline Sudan & 1.569 & 1.595 & 1.585 \\
\hline Cote d'Ivoire & 1.697 & 1.704 & 1.575 \\
\hline Tanzania & 1.735 & 1.765 & 1.568 \\
\hline Paraguay & 1.553 & 1.575 & 1.558 \\
\hline Uzbekistan & 1.703 & 1.74 & 1.558 \\
\hline Zambia & 1.453 & 1.656 & 1.556 \\
\hline Angola & 1.582 & 1.756 & 1.544 \\
\hline Afghanistan & 1.45 & 1.67 & 1.543 \\
\hline Senegal & 1.621 & 1.662 & 1.542 \\
\hline Uganda & 1.565 & 1.626 & 1.525 \\
\hline Nepal & 1.452 & 1.49 & 1.516 \\
\hline Cambodia & 1.567 & 1.89 & 1.509 \\
\hline Congo & 1.455 & 1.63 & 1.508 \\
\hline Cameroon & 1.579 & 1.626 & 1.505 \\
\hline El Salvador & 1.631 & 1.636 & 1.501 \\
\hline Montenegro & 0.42 & 1.279 & 1.499 \\
\hline Mozambique & 1.49 & 1.529 & 1.476 \\
\hline Myanmar & 1.519 & 1.477 & 1.454 \\
\hline Honduras & 1.56 & 1.571 & 1.454 \\
\hline Cuba & 1.842 & 1.736 & 1.443 \\
\hline Palestine & 0.991 & 1.39 & 1.412 \\
\hline Nicaragua & 1.538 & 1.501 & 1.404 \\
\hline Namibia & 1.504 & 1.492 & 1.372 \\
\hline Zimbabwe & 1.496 & 1.419 & 1.352 \\
\hline Mali & 1.412 & 1.407 & 1.344 \\
\hline Togo & 1.317 & 1.303 & 1.34 \\
\hline
\end{tabular}


Zinkina Yu.V. et al. RUDN Journal of Sociology, 2018, 18 (2), 271-283

Continuation of the table 1

\begin{tabular}{|c|c|c|c|}
\hline Country & $2000-2004$ & $2005-2009$ & $2010-2017$ \\
\hline Trinidad and Tobago & 1.509 & 1.531 & 1.32 \\
\hline Benin & 1.301 & 1.315 & 1.302 \\
\hline Liberia & 1.637 & 1.599 & 1.296 \\
\hline Congo & 1.307 & 1.367 & 1.277 \\
\hline Barbados & 1.501 & 1.374 & 1.276 \\
\hline Gabon & 1.472 & 1.48 & 1.255 \\
\hline Jamaica & 1.56 & 1.43 & 1.237 \\
\hline Botswana & 1.201 & 1.239 & 1.219 \\
\hline Burkina Faso & 1.255 & 1.272 & 1.219 \\
\hline Rwanda & 1.2 & 1.241 & 1.219 \\
\hline Mauritania & 1.27 & 1.282 & 1.219 \\
\hline Malawi & 1.321 & 1.325 & 1.216 \\
\hline Guinea & 1.398 & 1.428 & 1.205 \\
\hline Niger & 1.231 & 1.24 & 1.199 \\
\hline Korea & 1.271 & 1.259 & 1.171 \\
\hline Mongolia & 1.079 & 1.111 & 1.113 \\
\hline Somalia & 1.13 & 1.106 & 1.103 \\
\hline Tajikistan & 1.267 & 1.273 & 1.099 \\
\hline Turkmenistan & 1.269 & 1.194 & 1.086 \\
\hline Madagascar & 1.17 & 1.21 & 1.075 \\
\hline Sierra Leone & 1.221 & 1.158 & 1.07 \\
\hline Burundi & 1.041 & 1.089 & 1.045 \\
\hline Belize & 1.151 & 1.19 & 1.021 \\
\hline Brunei & 1.224 & 1.325 & 1.007 \\
\hline Swaziland & 1.047 & 1.047 & 0.991 \\
\hline Guyana & 1.133 & 1.114 & 0.989 \\
\hline Lao & 1.058 & 1.053 & 0.975 \\
\hline Gambia & 1.058 & 1.012 & 0.962 \\
\hline Cabo Verde & 1.076 & 1.081 & 0.959 \\
\hline Seychelles & 1.095 & 1.225 & 0.949 \\
\hline Haiti & 0.955 & 0.986 & 0.94 \\
\hline Suriname & 1.062 & 1.075 & 0.93 \\
\hline Eritrea & 1.106 & 0.943 & 0.919 \\
\hline Papua New Guinea & 1.042 & 0.832 & 0.886 \\
\hline Central African Republic & 0.87 & 0.911 & 0.86 \\
\hline Chad & 0.954 & 0.942 & 0.851 \\
\hline Antigua and Barbuda & 0.949 & 1.059 & 0.847 \\
\hline Fiji & 1.02 & 0.969 & 0.841 \\
\hline Andorra & 0.996 & 1.001 & 0.803 \\
\hline Maldives & 0.857 & 0.855 & 0.783 \\
\hline Dominica & 0.88 & 0.863 & 0.757 \\
\hline Saint Vincent and the Grenadines & 0.817 & 0.825 & 0.754 \\
\hline Gibraltar & 0,972 & 1,038 & 0,731 \\
\hline Equatorial Guinea & 0,677 & 0,827 & 0,726 \\
\hline Saint Kitts and Nevis & 0,654 & 0,706 & 0,682 \\
\hline Lesotho & 0,719 & 0,604 & 0,64 \\
\hline Guinea-Bissau & 0,736 & 0,69 & 0,632 \\
\hline Marshall Islands & 0,447 & 0,632 & 0,631 \\
\hline Samoa & 0.614 & 0.63 & 0.625 \\
\hline Bhutan & 0.491 & 0.644 & 0.584 \\
\hline South Sudan & 0.263 & 0.247 & 0.564 \\
\hline Greenland & 0.607 & 0.631 & 0.548 \\
\hline Djibouti & 0.585 & 0.704 & 0.54 \\
\hline Vanuatu & 0.529 & 0.579 & 0.536 \\
\hline Saint Lucia & 0.819 & 0.798 & 0.531 \\
\hline Timor-Leste & 0.522 & 0.511 & 0.515 \\
\hline
\end{tabular}


End of the table 1

\begin{tabular}{|l|c|c|c|}
\hline \multicolumn{1}{|c|}{ Country } & $2000-2004$ & $2005-2009$ & $2010-2017$ \\
\hline Grenada & 0.857 & 0.831 & 0.509 \\
\hline Sao Tome and Principe & 0.524 & 0.521 & 0.503 \\
\hline Solomon Islands & 0.478 & 0.506 & 0.488 \\
\hline Tonga & 0.454 & 0.476 & 0.456 \\
\hline Comoros & 0.547 & 0.611 & 0.431 \\
\hline San Marino & 0.351 & 0.495 & 0.425 \\
\hline Micronesia & 0.382 & 0.395 & 0.349 \\
\hline Kiribati & 0.334 & 0.35 & 0.349 \\
\hline Palau & 0.231 & 0.327 & 0.31 \\
\hline Tuvalu & 0.257 & 0.251 & 0.203 \\
\hline Holy See (Vatican City State) & 0.103 & 0.165 & 0.156 \\
\hline
\end{tabular}

We classify all countries into six groups according to their global connectivity rates:

1) "the leaders" (top 6 countries with connectivity rates from 3.99 to 4.00 in 2010-2017);

2) 19 highly connected countries $\left(7^{\text {th }}\right.$ to $25^{\text {th }}$ with connectivity rates from 3.75 to 3.99 );

3) 23 highly-medium connected countries $\left(26^{\text {th }}\right.$ to $48^{\text {th }}$ with connectivity rates from 3 to 3.75 );

4) 30 medium-connected countries ( $49^{\text {th }}$ to $78^{\text {th }}$ with connectivity rates from 2 to 3 );

5) 76 low-connected countries ( $79^{\text {th }}$ to $154^{\text {th }}$ with connectivity rates from 1 to 2$)$;

6) 43 lowest-low-connected countries $\left(155^{\text {th }}\right.$ to $197^{\text {th }}$ with connectivity rates from 0 to 1 ).

For each group, we calculated the total annual population for the period from 1970 to 2017, and the future annual population according to the United Nations Population Division medium scenario until 2100. The real and future population dynamics for all six groups is presented in Figure 1. We assume that countries will stay in the same groups though this is a simplification for countries can experience an increase or decrease in global connectivity rates and move to another group. However, although the values of the countries' global connectivity rates can fluctuate, countries quite rarely move from one group to another especially the low-connected countries. Thus, taking into account that the real situation will be less static, we can study real and possible population dynamics for six groups (identified according to the 2010 global connectivity rates).

The group of highly-connected countries is the most populous one though it is not the most numerous one in terms of the number of countries. This is mainly due to the fact that two world giants, China and India, are in the group. About a half of the global population ( 3.46 billion people) lives in the highly-connected countries. The low-connected group comes second in terms of the size of population (1.15 billion), it is followed by the medium-connected countries (with the total number of population close to 1.15 billion). In the highly-medium group of countries, there are about of 0.94 billion people, approximately 0.64 billion live in the highest connected countries, and 0.085 - in the lowest-low connected countries. 
4500

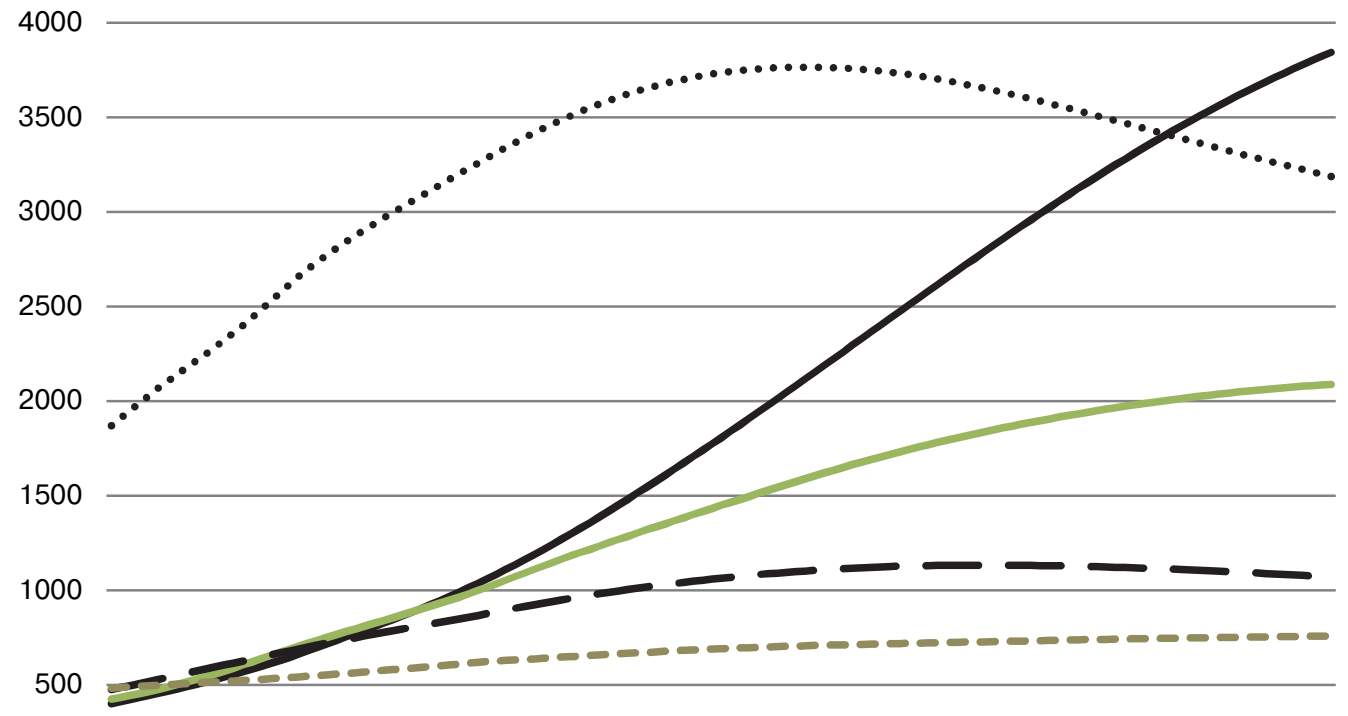

0 - - - - - - - - - - - - - - - - - - - - - -

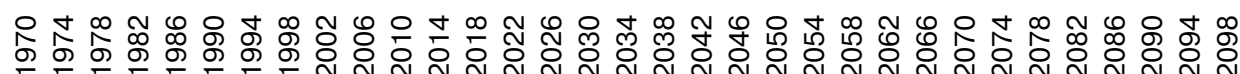

$-\cdots[0,1] \longrightarrow(1,2] \longrightarrow(2,3] \longrightarrow(3,3.75] \cdots \cdots(3.75,3.99]-\cdots(3.99,4]$

Figure 1. Real and possible population dynamics for six groups (according to the 2010 global connectivity rates), thousands

Source: authors' calculations based on the UN Population Division medium scenario [24]

Absolute numbers and shares of world population in six groups of countries with different global connectivity rates in 2017, 2050, and 2100

\begin{tabular}{|l|c|c|c|c|c|c|}
\hline \multicolumn{1}{|c|}{$\begin{array}{c}\text { Country } \\
\text { group }\end{array}$} & $\begin{array}{c}\text { Population } \\
\text { in 2017, mln }\end{array}$ & $\begin{array}{c}\text { Population } \\
\text { in 2050, mln }\end{array}$ & $\begin{array}{c}\text { Population } \\
\text { in 2100, mln }\end{array}$ & $\begin{array}{c}\text { Population } \\
\text { in 2017, \% } \\
\text { of world total }\end{array}$ & $\begin{array}{c}\text { Population } \\
\text { in 2050, \% } \\
\text { of world total }\end{array}$ & $\begin{array}{c}\text { Population } \\
\text { in 2100, } \\
\text { of world total }\end{array}$ \\
\hline $\begin{array}{l}\text { Highest } \\
\text { connected }\end{array}$ & 643.4 & 714.3 & 757.9 & 8.7 & 7.3 & 6.8 \\
\hline $\begin{array}{l}\text { Highly- } \\
\text { connected }\end{array}$ & 3464.1 & 3752.8 & 3186.3 & 46.6 & 38.5 & 28.5 \\
\hline $\begin{array}{l}\text { Highly- } \\
\text { medium- } \\
\text { connected }\end{array}$ & 941.3 & 1118.9 & 1070.2 & 12.7 & 11.5 & 9.6 \\
\hline $\begin{array}{l}\text { Medium- } \\
\text { connected }\end{array}$ & 1146.1 & 1677.9 & 2088.0 & 15.4 & 17.2 & 18.7 \\
\hline $\begin{array}{l}\text { Low- } \\
\text { connected }\end{array}$ & 1146.1 & 2331.5 & 3843.2 & 15.4 & 23.9 & 34.4 \\
\hline $\begin{array}{l}\text { Lowest-low- } \\
\text { connected }\end{array}$ & 85.3 & 149.1 & 218.6 & 1.1 & 1.5 & 2.0 \\
\hline
\end{tabular}


The situation is to dramatically change in the coming decades due to the following key trends: the proportion of population in the highest-, highly- and highly-mediumconnected countries will decline by 2050 and further by 2100 , while the proportions of population in the medium- and low-connected (and to some extent in the lowest-low connected) countries will significantly grow (Table 2). The highest growth of the proportion of world population is expected in the low-connected countries: now there are $15.4 \%$ of the world population, this figure is expected to increase by 1.5 times by 2050 and will double by the end of the century. The absolute number of the population of this group is likely to double by 2050 and triple by 2100 . On the contrary, the share of people living in the highly-connected countries is expected to significantly drop (by 1.5 times by 2100): their absolute number will continue to slightly grow until the late 2040s, but will slightly drop in the second half of the century.

Thus, most of the likely re-distribution of the world population is to take place not due to huge migration flows but as a result of the global demographic transition taking different rates in various countries, which determines different demographic situations. Most countries in the highest- and highly-connected groups have already (or almost) completed their demographic transitions either through a long 'natural' process (like most European countries) or due to specific state policies aimed at reducing fertility (like in China and India). This means that their fertility rates are close or below the simple reproduction level, so according to the United Nations' medium demographic scenario most of these countries will face a certain population decline by 2050 and further in 2050 - 2100. On the other hand, the low-connected group mainly consists of countries delayed in their demographic transition due to the still high fertility rates, and this is particularly the case for the Tropical African countries $[15 ; 16 ; 18 ; 30 ; 31]$. In these countries, there are large cohorts of youths and children, i.e. huge demographic inertia: even if the demographic transition accelerates immediately, their population will still double in the next decades $[15 ; 30]$.

This assumption raises another question - how accurate are these estimates? In fact, we have a scenario forecast, not a probability forecast, i.e. even UN Population Division does not insist that this scenario is the most probable one. However, its probability is high especially for the nearest decades (as most of the people living during these decades have already been born). Moreover, our forecasts are based on the assumptions regarding globalization such as that the changes in the global connectivity rates will not make countries change their groups. How valid is this assumption under the national globalization rates being rather volatile? For example, according to the Ernst\&Young/Economist Intelligence Unit index, France got +6 positions in the globalization ranking between 2011 and 2012, while Taiwan and Israel showed a decline [9]. We think this volatility is largely determined by the approach chosen to 'measure' globalization (i.e. by the indices themselves). These changes can mean not that a country is becoming more or less globalized, but that one or two indicators in the index have changed (i.e. there are some change in trade volumes due to the changed tariffs, etc.) [32]. 
According to the network analysis the global connectivity changes more slowly than the globalization indices imply. Certainly, there were changes in the countries' global connectivity rates; however, our research shows that in 2005-2010 only 2 out of 237 countries (India and Singapore) moved to a higher-value group (from the highlymedium- to the highly-connected). For comparison: in 2000-2010 10 out of 237 countries moved to a higher-value group: Brazil, Russia, India, Singapore (from the highlymedium- to the highly-connected); Romania, Chile (from the medium- to the highlymedium-connected); Mauritius, Serbia (from the low- to the medium-connected); Palestine, Montenegro (from the lowest-low to the low-connected).

Let us consider changes in the global connectivity rates in absolute values. Only four countries showed a significant growth (by more than 0.5 points) in the rates from 2000 - 2004 to 2010 - 2017; ten more countries showed a considerably large (by 0.25 0.5 points) growth. However, if we do not take into account small island states (high volatility of global connectivity rates is due to the very size of the states), there are three (Montenegro, Serbia, Chile) and nine (Romania, Mauritius, Palestine, India, Malta, Nigeria, Pakistan, Mexico, Russia) countries cases left. Eight out of these twelve countries already belonged to the high-medium- or medium-connected groups in 2000 . As for the low- and lowest-low-connected countries, only four of them achieved a considerable increase in the global connectivity rates. Two out of these four (Serbia and Montenegro) showed the highest growth in our sample, but this is due to the restoration after serious conflicts, which was certainly not the only factor of their failures but had a considerable impact (trade and FDI flows revived with peace). In general, it is a hard task for the low- or lowest-low-connected country to increase the global connectivity or to move to a higher group.

What are the conclusions of our research: first, though the countries' global connectivity rates change from year to year, only a limited number of countries manage to move to a higher group, and no country managed to move by two or three groups higher. Second, we usually witness changes in the positions of the countries with high connectivity rates. Among the lower-connected countries, only four moved to higher connectivity groups in 2000 - 2010: three of them (Serbia, Montenegro, and Palestine) restored their economies after serious conflicts, which certainly contributed to this growth (along with other factors), and the forth is a very small country Mauritius (both globalization indices and network connectivity measures are more volatile for small countries than for larger economies due to the higher relative volatility of national economic indicators). Thus, it is a challenging task for a low-connected country to significantly increase its global connectivity rates; so most low- and lowest-low-connected countries (especially the larger ones) will likely to retain comparatively low levels of global connectivity. Under the expected population doubling in this group by 2050, we can expect a certain de-globalization with significantly more people living in the low-globalized parts of the world [on the previous waves of globalization and de-globalization see: $7 ; 12 ; 17$ ].

\section{REFERENCES}

[1] Apt W. Germany's New Security Demographics: Military Recruitment in the Era of Population Aging. Springer Science \& Business Media; 2013.

[2] Borgatti SP., Everett MG., Johnson JC. Analyzing Social Networks. Sage Publications; 2013. 
[3] Castells M. The Information Age: Economy, Society, and Culture. Vol. I: The Rise of the Network Society, Wiley-Blackwell; 1996.

[4] Castells M. Information Technology, Globalization, and Social Development. Geneva: United Nations Research Institute for Social Development; 1999.

[5] Castells M. The Rise of the Network Society: The Information Age: Economy, Society, and Culture (Vol. 1). John Wiley \& Sons; 2011.

[6] Candau F. Trade, FDI and Migration. International Economic Journal. 2013: 27(3): 441— 461.

[7] Chase-Dunn C., Kawano Y., Brewer B. Trade globalization since 1795: Waves of integration in the world-system. American Sociological Review. 2000: 65 (1): 77-95.

[8] Coleman D., Rowthorn R. Who's afraid of population decline? A critical examination of its consequences. Population and Development Review. 2011: 37 (1): 217-248.

[9] Ernst \& Young. Looking beyond the Obvious. Globalization and New Opportunities for Growth. About the 2012 Globalization Index. 2012. http://www.ey.com/GL/en/Issues/Drivinggrowth/Globalization---Looking-beyond-the-obvious---2012-Index.

[10] Goldstone J.A., Kaufmann E.P., Toft M.D. (Eds.). Political Demography: How Population Changes are Reshaping International Security and National Politics. Oxford University Press; 2012.

[11] Goldstone J.A., Marshall M.G., Root H. Demographic growth in dangerous places: Concentrating conflict risks. International Area Studies Review. 2014: 17 (2): 120-133.

[12] Grinin L.E., Korotayev A.V. Social macroevolution: Growth of the world system integrity and a system of phase transitions. World Futures. 2009: 65 (7): 477-506.

[13] Grinin L.E., Korotayev A.V. Will the global crisis lead to global transformations? 1. The global financial system: Pros and cons. Journal of Globalization Studies. 2010: 1 (1): 70—89.

[14] Kim T., Sciubba J.D. The effect of age structure on the abrogation of military alliances. International Interactions. 2015: 41 (2): 279-308.

[15] Korotayev A., Zinkina Yu. How to optimize fertility and prevent humanitarian catastrophes in Tropical Africa. African Studies in Russia. 2014: 6: 94-107.

[16] Korotayev A., Zinkina Yu. East Africa in the Malthusian trap? Journal of Developing Societies. 2015: 31 (3): 385-420.

[17] Korotayev A., Zinkina Yu., Andreev A. Secular cycles and millennial trends. Cliodynamics. 2016: 7 (2): 204-216.

[18] Korotayev A., Zinkina Yu., Goldstone J., Shulgin S. Explaining current fertility dynamics in Tropical Africa from an anthropological perspective: A cross-cultural investigation. CrossCultural Research. 2016: 50 (3): 251-280.

[19] Modelski G. Globalization as evolutionary process. In: Modelski G., Devezas T., Thompson W.R. (Eds.). Globalization as Evolutionary Process: Modeling Global Change. London-New York: Routledge; 2008. P. 11-29.

[20] Sciubba J.D. The Future Faces of War. Population and National Security; Santa Barbara: Praeger; 2011.

[21] Shulgin S., Zinkina Yu., Andreev A. Method of analysis of the global trade network structure. Ekonomika i Upravlenie: Provlemy, Resheniya. 2016: 12: 48-56 (In Russ.).

[22] Shulgin S., Zinkina Yu., Andreev A. Measuring globalization: Network approach to countries' global connectivity rates and their evolution in time. Social Evolution and History. 2018 (forthcoming).

[23] Teitelbaum M.S. Political demography: Powerful trends under-attended by demographic science. Population Studies. 2015: 69: 87-95.

[24] United Nations, Department of Economic and Social Affairs (UN DESA), Population Division. World Population Prospects: The 2017 Revision. https://esa.un.org/unpd/wpp.

[25] United Nations. UN Comtrade Database. 2017. https://comtrade.un.org.

[26] United Nations. International Migrant Stock by Destination and Origin. 2015.

[27] Weiner M., Russell S.S. (Eds.). Demography and National Security. Berghahn Books; 2001.

[28] World Bank. Trade in Services Database. 2017 https://data.worldbank.org/data-catalog/tradein-services. 
[29] Yoshihara S., Sylva D.A. (Eds). Population Decline and the Remaking of Great Power Politics. Potomac Books; 2012.

[30] Zinkina Yu., Korotayev A. Explosive population growth in tropical Africa: Crucial omission in development forecasts - emerging risks and way out. World Futures. 2014: 70 (2): 120 - 139.

[31] Zinkina Yu., Korotayev A. Projecting Mozambique's demographic futures. Journal of Futures Studies. 2014: 19 (2): 21 - 40.

[32] Zinkina Yu., Korotayev A., Andreev A. Measuring globalization: Existing methods and their implications for teaching global studies and forecasting. Campus-Wide Information Systems. 2013: 30 (5): $321-339$.

\title{
НЕКОТОРЫЕ ПОСЛЕДСТВИЯ ИЗМЕНЕНИЙ В РАСПРЕДЕЛЕНИИ НАСЕЛЕНИЯ МИРА: НАСКОЛЬКО ГЛОБАЛИЗИРОВАННЫМ ОСТАНЕТСЯ МИР?*
}

\author{
Ю.В. Зинькина ${ }^{1,2}$, С.Г. Шульгин ${ }^{1}$, И.А. Алешковский², \\ А.И. Андреев ${ }^{2}$ \\ ${ }^{1}$ Российская академия народного хозяйства и государственной службы \\ при Президенте Российской Федерации \\ Просп. Вернадского, 84, Москва, 119571, Россия \\ ${ }^{2}$ Московский государственный университет им. М.В. Ломоносова \\ Ленинские горы, 1-51, Москва, 119991, Россия \\ (e-mail: juliazin@list.ru; sergey@shulgin.ru; \\ andreev@fgp.msu.ru; aleshkovski@fgp.msu.ru)
}

Жителям стран Первого мира глобализация кажется всеобъемлющим феноменом, однако на самом деле уровни включенности стран в глобализационные процессы серьезно различаются. А как ситуация изменится, скажем, через пятьдесят лет? Цель статьи - показать, как прогнозируемые демографические изменения могут повлиять на относительную и абсолютную численность населения стран, различающихся по уровню глобализированности. Исследование авторов основано на данных об участии стран в глобальных сетях торговли товарами и услугами, прямых иностранных инвестициях и международной миграции, а также на среднем сценарном прогнозе численности населения, опубликованном отделом народонаселения ООН в 2017 году. В исследовании применялся двухступенчатый подход: сначала были сконструированы сетевые модели и проанализированы структуры сетей для определения положения в них отдельных стран, что позволило оценить степень их глобализированности, а затем объединить в шесть групп в зависимости от уровней глобализированности. На втором этапе исследования результаты сетевого анализа были сопоставлены с демографическими данными, чтобы оценить, сколько людей, согласно прогнозам, будет проживать в странах разного уровня глобализированности в ближайшие десятилетия (до 2050 года) и в более отдаленной перспективе (2100). Результаты исследования показали, что примерно половина населения мира (3,46 млрд) в настоящее время проживает в странах с высоким уровнем глобализированности, однако эта ситуация, по всей вероятности, серьезно изменится в ближайшие десятилетия. Авторы делают вывод, что доля мирового населения, проживающего в странах с самыми высокими и относительно высокими уровнями глобализированности, сократится к 2050 году и продолжит снижение к 2100 году. В то же время доля населения, проживающего в странах с относительно и самыми низкими уровнями глобализированности, существенно возрастет.

Ключевые слова: глобализация; глобальная связанность; измерения глобализации; демографические прогнозы; население мира; прогноз численности населения

* ( ) Зинькина Ю.В., Шульгин С.Г., Алешковский И.А., Андреев А.И.

Исследование выполнено при поддержке Российского научного фонда. Проект № 17-78-20096. 